\title{
Before \& After the Antikythera Mechanism
}

Summary of talk given at Kestari Meeting, "From Antikythera to the SKA: Lessons from the Ancients" 11-15 June 2012

Mike Edmunds, School of Physics \& Astronomy, Cardiff University \& Antikythera Mechanism Research Project

I want to discuss several aspects which were raised in Theodosis Tassios' talk at this meeting, and in his excellent paper (Theodosis 2012) in the Catalogue of the current Antikythera Wreck exhibition in the National Archaeological Museum of Athens. In particular I would like to raise the issues:

- How widespread were machines like the Antikythera Mechanism in the ancient World?

- Why and when did the technology disappear and then reappear?

- Did such devices influence views about Cosmology? - although this important aspect I will have to leave the for another day!

I have been trying to find all literature references to such machines, undoubtedly known in Greek as sphairai (Latin sphaerae) spherae" - whether spherical or circular - but my list (to be discussed and published in full elsewhere) is probably very incomplete, and I would welcome additions to it. The major reference (I'll call it number zero!) must be to Archimedes' (287-212 BC) lost book on sphere-making

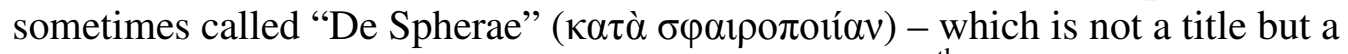
description. It is mentioned by Pappus of Alexandria ( $4^{\text {th }} \mathrm{C}$ AD) on the authority of Carpus of Antioch, and in Proclus on Euclid. Perhaps it may turn up one day in excavation of an ancient library, or in palimpsest. The references come from Heath (1921) which he gives as Pappus viii, p1026, 9; Proclus , p41,16. For the rest so far, see Table 1. It is perhaps interesting that only the latest reference, the lamentable Egyptian-Greek poet Nonnus, mentions use of such a machine for astrology, although one suspects that his account is based on hearsay rather than first-hand encounter. The list shows awareness of sphaerae over a 600 year period, and almost reaches the geared Byzantine sundial (Field \& Wright, 1985) of c. 520 AD. It must be admitted that many of the references refer just to Archimedes' famous work, but at least four are independent and imply a continuing tradition.

In looking at the context of mechanisms in the classical era, a particularly interesting reference is Vitruvius (born c. 80-70 BC, died after c. 15 BC) who in De Architectura Book 1 describes the training of an architect in a way that would suggest skills ideal for the construction of sphaerae " .....a man who is to follow the architectural profession......should be a man of letters, a skilful draughtsman, a mathematician, ......familiar with astronomy and astronomical calculations.". The reference to drawing is important - it implies that mechanical drawings would have existed. But it cannot be emphasised too strongly that no mechanical drawings survive for our period approx $300 \mathrm{BCE}$ to $400 \mathrm{AD}$. All surviving drawings are later copies - and hence very unreliable when it comes to interpretation, since the copyists often seem to have no idea about what they were copying - for example what the tooth profile on gears actually was. Where later scribes $d o$ have experience of mechanism there can be the inverse danger of them imposing later ideas on what they are copying. My suspicion is that all teeth of metal gears were essentially triangular until 1300-1350 AD, except for worm gears or ratchet and pawls. But there seems little reason to doubt that there 
were gears. Vitruvius in de Architectura Book 9 describes a water-clock by Ctesibius (fl. 285-222 BC) which must date around $265-220$ BC, which had a floating drum "...called a tympanum on which is placed a rule fitted with a revolvable wheel with equal teeth, which teeth, acting on one another, produce measured revolutions and motion." - or in the original Latin " "tympanum dicitur in quo conlocata est regula versatili tympano denticulis aequalibus perfecta. qui denticuli alius alium inpellentes versationes modicas faciunt et motiones." Now the word $\tau v \mu \pi \alpha$ viov (the diminutive of $\tau \tilde{\mu} \mu \pi \alpha v o v$ which Vitruvius is transliterating)

Table 1. Classical references to "spherae" or similar mechanisms

\begin{tabular}{|c|c|c|c|c|}
\hline Ref No. & Author & Work & Date & What described \\
\hline 0 & Archimedes & $\begin{array}{l}\text { "De } \\
\text { Sphaerae", } \\
\text { see text }\end{array}$ & $\begin{array}{l}\text { C 260?- } \\
212 \text { BC }\end{array}$ & See text \\
\hline 1 & Cicero & $\begin{array}{l}\text { De Re Publica } \\
1,14\end{array}$ & $54-51 \mathrm{BC}$ & Archimedes Sphaerae \\
\hline $2 \mathrm{~A}$ & Cicero & $\begin{array}{l}\text { De natura } \\
\text { deorum } \\
\text { II, xxxiv }\end{array}$ & & "Posidonius" sphaera \\
\hline $2 \mathrm{~B}$ & Cicero & $\begin{array}{l}\text { De natura } \\
\text { deorum } \\
\text { II, xcvii }\end{array}$ & & $\begin{array}{l}\text { Sphaera, horae [clocks] and } \\
\text { other devices set in motion } \\
\text { "cum machinatione quandum" } \\
\text { ("by some mechanism") }\end{array}$ \\
\hline 3 & Cicero & $\begin{array}{l}\text { Tusculan } \\
\text { Disputations } \\
1,36\end{array}$ & & Archimedes sphaerae \\
\hline 4 & Ptolemy & $\begin{array}{l}\text { Almagest } \\
\text { XIII, } 2\end{array}$ & $\begin{array}{l}120-140 \\
\mathrm{AD}\end{array}$ & $\begin{array}{l}\text { "models constructed on } \\
\text { earth..." }\end{array}$ \\
\hline 5 & \begin{tabular}{|l} 
Sextus \\
Empiricus
\end{tabular} & $\begin{array}{l}\text { Adversus } \\
\text { mathematicos, } \\
\text { IX, } 115\end{array}$ & $3 r d C A D$ & $\begin{array}{l}\text { Archimedean sphere... amazed } \\
\text { by...the devices and causes of } \\
\text { the movements. }\end{array}$ \\
\hline 6 & Pappus & $\begin{array}{l}\text { Collection } \\
\text { Book 8, } 2\end{array}$ & 3rd C AD & $\begin{array}{l}\text { Spheres..motions. } \\
\text {..Archimedes.. }\end{array}$ \\
\hline 7 & Lactantius & $\begin{array}{l}\text { Institutiones } \\
\text { divinae II, } 5 \\
18\end{array}$ & 4th C AD & Archimedes sphaerae \\
\hline 8 & Claudian & $\begin{array}{l}\text { Carmina } \\
\text { minora LI } \\
(\text { LXVIII) }\end{array}$ & $\begin{array}{l}\text { ca. } 400 \\
\text { AD }\end{array}$ & Archimedes sphaerae \\
\hline
\end{tabular}




\begin{tabular}{|l|l|l|l|l|}
\hline 9 & $\begin{array}{l}\text { Agrestius } \\
\text { Chromatius } \\
\text { quoted by } \\
\text { St Sebastian } \\
\text { and St } \\
\text { Polycarp }\end{array}$ & & 3rd C AD & $\begin{array}{l}\text { Cubiculum holovitrium ("glass } \\
\text { chamber") with moon phase } \\
\text { and planets }\end{array}$ \\
\hline 10 & Nonnus & Dionysiaca & 5th C AD & $\begin{array}{l}\text { Sphaera with planets, used for } \\
\text { astrology }\end{array}$ \\
\hline
\end{tabular}

“"tympanum" appears in the inscription text on the Antikythera Mechanism (although the particular part referred to may be a disk) - and given the description Vitruvius uses it seems very reasonable that he knew metal gears were being used in $100 \mathrm{BC}$ (as of course we know from the Antikythera Mechanism), and not too much of a stretch to assume they were known to Cestibius and his near contemporary Archimedes.

So should we really be surprised by the Antikythera Mechanism? In some sense, no we should not. There certainly seems to be a sense of amazement when people today first learn of its existence and details. But of course people in any era tend to interpret history through the eyes of their current society, and the recent rate of change of technology and perhaps a rather hazy view of the Classical World may have given us a rather biased view of ancient Greek capabilities. A salutary correction can come from the Cyclopaedia of Arts, Sciences and Literature by Abraham Rees, DD, FRS, FLS etc etc, published in 1810 in London. Remember this was way before the discovery of the Antikythera Mechanism, but at a time when a formal education in the Greek and Latin classics would have been normal for scholars, and hence perhaps allowing a rather closer and more admiring view of ancient Greek abilities. In the Cyclopaedia article on "Planetary Machines" we find " "...Archimedes... there can be no doubt that but that wheels and pinions were introduced to his sphere to produce the respective motions", and in the Cyclopaedia "pinions" are defined as gear wheels. So no surprise there - but of course what could not have been expected was the particularly subtle and elegant mechanical design that the Antikythera Mechanism shows in its representation of the first lunar anomaly.

So what happened to the technology? One aspect may perhaps be found in reference 10 of Table 1, where a device "in which the whole learning and science of the stars is constructed mechanically...." invoked the reaction that "monstrous demons displayed an art hostile to the deity" implying religious suppression, possibly due to increasing astrological emphasis from around $50 \mathrm{BC}$ onwards.

Before moving on to later developments I will mention briefly an initial study of the likely mechanical accuracy of the Antikythera Mechanism (Edmunds 2011). Based on estimates of the variation in positions of the teeth measured in CT scans of the gears, computational models of the gear trains were generated with a selection of random and systematic errors. A "best guess" set of parameters generates a performance such that the Metonic month indicator is on average 2 days away, and the Saros indicator on average 5 days away, from what the designer would have intended. This is 
probably a satisfactory performance - since, for example, an eclipse must occur at either the full or new moon and all that need be known is whether such an eclipse is likely in that particular month. These are average values, and larger deviations would occur during the complete cycles - for example, half the set of simulated mechanisms would have a deviation as large (or larger) than 6 and 12 days for the Metonic and Saros indicators at some time during the cycle - so it is possible that an eclipse might be predicted in the wrong month. The lunar pointer is geared up from the main drive, and hence angular errors are larger. The moon pointer could easily be as far as 20 degrees away from the intended position at some time during the year. Indication of new or full moon might typically be wrong by a day or so - but perhaps we should not be surprised at this, since setting the exact day by a pointer (possibly simply the Sun pointer) on the front dial to $1 / 356$ of a revolution might not have been particularly easy, and we are not aware of any subsidiary dial to help with this. The implication may be that the device is for display purposes, rather than for really accurate calculation.

These error calculation may have another implication. It is interesting to speculate on what other mechanisms (the "cum machinatione" of the Cicero reference $2 \mathrm{~B}$ in Table 1) would have been possible for the ancient Greeks. Since the Roman world had huge financial accounting and surveying calculation requirements, a mechanical calculator might be a possibility. The existence of cheap labour with an abacus might lessen the impetus to mechanisation, but the inaccuracies of gear trains with irregular triangulartoothed gears might also be a factor - a machine would just not have been accurate enough for equitable financial or land transactions. However, it might not have taken much development to achieve a satisfactory device, particularly given the level of ingenuity involved in the Antikythera Mechanism's lunar anomaly calculation. What is requires is a "discreteness", the positive clicking over in tallying which is characteristic of much later devices. Such a discreteness appears to have been incorporated into contemporary hodometers (eg Drachmann 1963) where gears were turned one tooth at a time by a pin on a revolving wheel, or discrete balls were let fall through holes in a wheel. A combination of such designs might have led to an accurate calculator - but, so far as we know, it did not. So back to the question of what did happen to the technology.

Table 2 (Incomplete) Timeline for Geared Astronomical Mechanisms from 500 AD

- Byzantine geared sundial $520 \mathrm{AD}$

- C.1000 AD Al Biruni geared calendar design (Hill 1985)

- $11^{\text {th }}$ C. AD William Abbott of Hirsham. Details unknown

- 1232 AD gift to Frederick II from Al-Ashraf Sultan of Damascus. Details unknown

- C.1300 Opus quorandum rotarum mirabilis - manuscript with functional specification and some gearing details (North 1966)

- 1292-1336 Richard of Wallingford. Major astronomical clock showing the movements of the planets (Tractatus Horologii Astronomici, printed and translated in North (1976).

- 1364 de Dondi: Major astronomical clock and manuscript description. (Ballie, Lloyd and Ward 1974)

Note: For developments (probably independent) in China c.1000-1200 A.D. see Needham, Ling and de Solar Price 1986) 
Table 2 shows a very elementary and incomplete timeline. The clock escapement mechanism, vital for reasonable timekeeping was probably invented around 1280 AD. I suggest that metal gear technology stuck at triangular teeth, with no great development (and little visibility) until c1300 - when there was a great explosion of innovation, probably following Arabic sources becoming available in Europe through the Moors in Spain. It has been suggested that a fragment of a more sophisticated gear with rounded teeth survives from Sardinia c.170-140 BC (http://www.giovannipastore.it/ARCHIMEDE.htm), but so far as I am aware the archaeological details of the find have not been published in a peer-reviewed journal, and from the gear's appearance one has to wonder whether this is actually a medieval interloper.

An interesting sidelight on mechanism comes from "The Book of Secrets" copied (usual health warnings about later copies!) in 1266 (in Toledo) from an original dating back to the eleventh century by the Andalusian engineer Ibn Khalaf al-Muradi. Some details are available at http://www.leonardo3.net/bookofsecrets/index_eng.html, with gears in the manuscript appearing to have "pin" teeth, rather than triangular teeth. The need for systematic study of Arabic and Byzantine sources cannot be overemphasised, to see exactly what did come through from Greece and Rome, and to check that there really was no significant development of the geared technology until c1300.

It is tempting to speculate on why some sort of industrial revolution did not occur in the classical world sometime between $100 \mathrm{BC}$ and $300 \mathrm{AD}$. The answer may come from looking at three criteria for revolution in D.S. Landes' 1969 study "The Unbound Prometheus". He suggest that necessary are (1) substitution of mechanical devices for human skill (2) inanimate power (replacing humans or animals) (3) improved raw material extraction, and later adds (4) increased size of production units. The Antikythera Mechanism technology certainly might begin to satisfy the first of these, but there does not seem to have been a huge advance towards the other criteria. If we add in the necessity for political, economic and social conditions to be suitable it is perhaps not surprising that a revolution did not occur. A similar argument might presumably be made for why the revolution did not occur in Tudor Britain, and only really blossomed a couple of hundred years later.

To summarise my conclusions:

- We should not be too surprised by existence of mechanical sphaerae between at least $250 \mathrm{BC}$ and $400 \mathrm{AD}$ - there appears to have been a tradition of making such machines

- We can be surprised by the sophistication of the mechanical design shown by the Antikythera Mechanism, although the metalworking skills were readily available as evidenced by contemporary jewellery. The acquisition of mechanical design skills was not enough by itself to drive an industrial revolution.

- There seems to have been a hiatus, stalling at triangular-toothed gears until c1200-1300, perhaps due to religious discouragement of devices that might be associated with astrology or alternative world-views, although the rebirth of interest in gearwork for timekeeping and astronomical clocks was apparently associated with monasteries. The idea of religious suppression may be overstated, and the hiatus may simply reflect a neglect of the possibilities. 
- Byzantine and Arab sources MUST be investigated further! - but beware of copied drawings.

It is as always a pleasure to thank my colleagues in the Antikythera Mechanism Research Project for their ideas, support and encouragement, and in particular Alexander Jones for very helpful detailed comments.

Baillie, G.H., Lloyd, H. Alan \& Ward F.A.B. The Planetarium of Giovanni de Dondi, The Antiquarian Horological Society, London, 1974

Drachmann, A.G. Mechanical Technology of Greek and Roman Antiquity, University of Wisconsin Press, 1963)

Edmunds, M.G. Journal for the History of Astronomy: xlii, 2011

J.V. Field \& M.T. Wright, Annals of Science, 42 (1985), pp. 87 - 138.

Heath, T. A History of Greek Mathematics, Clarendon Press, Oxford, (Reprinted Dover Publications 1981) Vol 2, p17, 1921

Hill, D.R., Annals of Science, 42, 1985, pp.139 - 163.

Landes, D.S. The Unbound Prometheus, Cambridge University Press, 1969

Needham, J., Ling, W. and de Solar Price, D. Heavenly Clockwork, Cambridge University Press, Second Edition, 1986

North, J.D. Physis, 8, 1966, pp 337-372, reprinted in Stars, Minds and Fate, 1989

North, J.D. Richard of Wallingford, Oxford University Press, Vol 1, p441, 1976

Theodosis, T. Prerequisites for the Antikythera Mechanism to be produced in the $2^{\text {nd }}$ Century BC, The Antikythera Shipwreck Eds N. Kaltsas, E. Vlachogianni \& P. Bouyia, National Archaeological Museum, Athens, p 249, 2012 